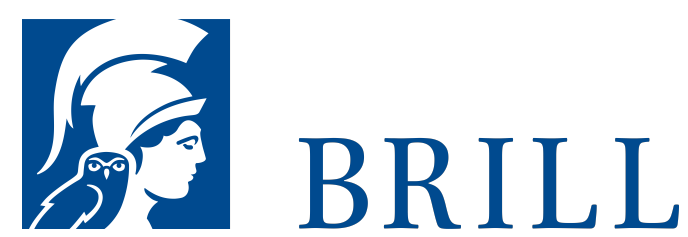

\title{
Athletics in Ancient Athens
}

Author: D.G. Kyle

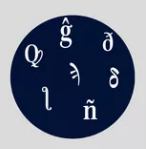

Language:

English

Subjects:

General,

Classical Studies

Publisher: Brill

Series:

Mnemosyne,

Supplements,

Volume: 95

Paperback

Publication date:

o1 Jun 1987

ISBN: 978-90-

04-07861-1 
For more information see brill.com

Order information: Order online at brill.com +44330 333 0049 | customerservices@brill.com Submission information: brill.com/authors

Titles published by Brill | Fink, Brill | mentis or Brill | Schöningh: +49(o)715413279216| brill@brocom.de 